\title{
Development of a genetic system for the deep-sea psychrophilic bacterium Pseudoalteromonas sp. SM9913
}

\author{
Zi-Chao Yu ${ }^{1,2}$, Dian-Li Zhao ${ }^{1,2}$, Li-Yuan Ran ${ }^{1,2}$, Zi-Hao Mi1 ${ }^{1,2}$, Zhao-Yu Wu ${ }^{1,2}$, Xiuhua Pang ${ }^{1,2}$, Xi-Ying Zhang ${ }^{1,2}$, \\ Hai-Nan Su ${ }^{1,2}$, Mei Shi ${ }^{1,2}$, Xiao-Yan Song ${ }^{1,2}$, Bin-Bin Xie ${ }^{1,2}$, Qi-Long Qin ${ }^{1,2}$, Bai-Cheng Zhou ${ }^{2}$, Xiu-Lan Chen ${ }^{1,2^{*}}$ \\ and Yu-Zhong Zhang ${ }^{1,2}$
}

\begin{abstract}
Background: Pseudoalteromonas species are a group of marine gammaproteobacteria frequently found in deep-sea sediments, which may play important roles in deep-sea sediment ecosystem. Although genome sequence analysis of Pseudoalteromonas has revealed some specific features associated with adaptation to the extreme deep-sea environment, it is still difficult to study how Pseudoalteromonas adapt to the deep-sea environment due to the lack of a genetic manipulation system. The aim of this study is to develop a genetic system in the deep-sea sedimentary bacterium Pseudoalteromonas sp. SM9913, making it possible to perform gene mutation by homologous recombination.

Results: The sensitivity of Pseudoalteromonas sp. SM9913 to antibiotic was investigated and the erythromycin resistance gene was chosen as the selective marker. A shuttle vector pOriT-4Em was constructed and transferred into Pseudoalteromonas sp. SM9913 through intergeneric conjugation with an efficiency of $1.8 \times 10^{-3}$, which is high enough to perform the gene knockout assay. A suicide vector pMT was constructed using pOriT-4Em as the bone vector and sacB gene as the counterselective marker. The epsT gene encoding the UDP-glucose lipid carrier transferase was selected as the target gene for inactivation by in-frame deletion. The epsT was in-frame deleted using a two-step integration-segregation strategy after transferring the suicide vector pMT into Pseudoalteromonas sp. SM9913. The $\Delta$ epsT mutant showed approximately $73 \%$ decrease in the yield of exopolysaccharides, indicating that epsT is an important gene involved in the EPS production of SM9913.

Conclusions: A conjugal transfer system was constructed in Pseudoalteromonas sp. SM9913 with a wide temperature range for selection and a high transfer efficiency, which will lay the foundation of genetic manipulation in this strain. The epsT gene of SM9913 was successfully deleted with no selective marker left in the chromosome of the host, which thus make it possible to knock out other genes in the same host. The construction of a gene knockout system for Pseudoalteromonas sp. SM9913 will contribute to the understanding of the molecular mechanism of how Pseudoalteromonas adapt to the deep-sea environment.
\end{abstract}

\section{Background}

The deep-sea floor constitutes almost $60 \%$ of the earth's surface [1], most of which is covered with fine-grained sediments [2]. The deep-sea sediments are a greatly dynamic geo- and biosphere, where no light is present, the temperature is as low as $-1^{\circ} \mathrm{C}$ to $4^{\circ} \mathrm{C}$ and the pressure is

\footnotetext{
* Correspondence: cxl0423@sdu.edu.cn

'State Key Laboratory of Microbial Technology, Shandong University, Jinan 250100, China

${ }^{2}$ Marine Biotechnology Research Center, Shandong University, Jinan 250100, China
}

up to 1,100 bar [2]. Despite these extreme conditions, various microorganisms flourish in deep-sea sediments. Approximately $13 \%$ of the total global bacteria have been found in the upper $10 \mathrm{~cm}$ of deep-sea sediments [3,4], which play an important role in the deep-sea ecosystem.

The extreme characteristics of the deep-sea sediments have compelled various bacteria to evolve special features to adapt to the deep-sea environment. However, the molecular mechanism of deep-sea bacteria adapted to deep-sea sediments is still largely unknown. By far, only several strains, such as Photobacterium profundum SS9

\section{Biomed Central}

(c) 2014 Yu et al.; licensee BioMed Central Ltd. This is an Open Access article distributed under the terms of the Creative Commons Attribution License (http://creativecommons.org/licenses/by/2.0), which permits unrestricted use, distribution, and reproduction in any medium, provided the original work is properly cited. The Creative Commons Public Domain Dedication waiver (http://creativecommons.org/publicdomain/zero/1.0/) applies to the data made available in this article, unless otherwise stated. 
and Shewanella piezotolerans WP3, have been well studied in their adaptation to the deep sea. Photobacterium profundum SS9, which was isolated from the Sulu Sea in Philippines at a depth of $2.5 \mathrm{~km} \mathrm{[5],} \mathrm{was} \mathrm{found} \mathrm{to}$ have many special genetic features in DNA replication, fidelity and structure [6,7], as well as membrane integrity and fluidity [8-10] to adapt to the high-pressure environment by Tn5 gene replacement mutagenesis. The environmental adaptation mechanisms of Shewanella piezotolerans WP3, a bacterium isolated from a western Pacific Ocean sediment sample at a depth of 1914 m [11], was also studied in the genomic level [12]. Furthermore, many genes of this strain were found to be regulated by cold shock [13], and the regulation of fatty acid biosynthesis and NAP- $\alpha$ system in response to different temperatures and pressures were studied by gene knockout $[14,15]$.

Pseudoalteromonas are widespread in various marine environments. Over 30 marine species with a large number of strains have been reported in this genus. Studies on these marine bacteria have suggested that they play important roles in marine ecosystem. However, by far in this genus, only one strain, Pseudoalteromonas haloplanktis TAC125 from the Antarctic seawater, has been reported to have a gene knockout genetic system [16]. Pseudoalteromonas strains are also frequently encountered in the analysis of deep-sea sedimentary bacterial diversity [17-19], implying that some bacteria in this genus may also play an important role in deep-sea sediment ecosystem. Some Pseudoalteromonas strains isolated from deep-sea sediments have been shown to be good extracellular enzyme producers or exopolysaccharide (EPS) producers [18,20-23]. It is reported that an electroporation transformation system was developed in Pseudoalteromonas sp. PS1M3 from deep-sea sediments [24]. Nevertheless, gene deletion has not been performed in this strain. Thus, gene knockout genetic system has not yet constructed in a deep-sea Pseudoalteromonas strain. Due to the lack of such genetic systems, little is yet known how Pseudoalteromonas adapt to the deep-sea environment at molecular level.

Pseudoalteromonas sp. SM9913 (hereafter called SM9913), isolated from the deep-sea sediment at $1855 \mathrm{~m}$ depth near the Okinawa Trough [25], is a psychrophilic strain capable of producing a great quantity of proteases [20,26,27] and EPS [21]. The genome of SM9913 has been sequenced, and some specific features implying how Pseudoalteromonas sp. SM9913 adapts to the deep-sea environment have been revealed in gene level [28]. However, it is still difficult to verify the predicted features by experiments due to the lack of a genetic system in SM9913. Therefore, it is necessary to develop a genetic system for the reverse genetics in SM9913 to investigate the molecular mechanism of how this bacterium adapts to the deep-sea sedimentary environment. In this study, a conjugal transfer system with high efficiency was constructed, and a gene knockout system in SM9913 was developed with the epsT gene encoding the initial UDP-glucose lipid carrier transferase as the target.

\section{Results and discussion}

\section{Sensitivity of SM9913 to six antibiotics}

The antibiotics sensitivity assay of SM9913 was performed with six antibiotics. The result showed that SM9913 was completely resistant to ampicillin, kanamycin, tetracycline and streptomycin, partly sensitive to chloromycetin and completely sensitive to erythromycin of $100 \mu \mathrm{g} / \mathrm{ml}$ (Table 1 ). This result is consistent with the information obtained from genome analyisis of SM9913. SM9913 harbors 12 multidrug-resistance genes, $4 \beta$-lactamase genes and genes encoding AcrA/E family efflux transporter and AcrB/AcrD/AcrF family protein in its genome [28]. These genes are all involved in drug resistance [29]. Although the growth of SM9913 was not completely restrained by $50 \mu \mathrm{g} / \mathrm{ml}$ erythromycin, SM9913 could not survive when erythromycin of $100 \mu \mathrm{g} / \mathrm{ml}$ were added to the medium. Therefore, $100 \mu \mathrm{g} / \mathrm{ml}$ erythromycin was used for screening SM9913 mutants in this study.

\section{Construction of the conjugal transfer system with high efficiency}

A shuttle vector, pOriT-4Em, which can replicate in both E. coli and SM9913, was constructed. As shown in Figure $1 \mathrm{~A}$, pOriT-4Em is characterized by the presence of a DNA fragment containing conjugative transfer initiation origin (OriT) and selective marker genes of ampicillin resistance gene $(A m p R)$ and erythromycin resistance gene $(E m R)$. The phage $\mathrm{f} 1$ region on pOriT-4Em is responsible for the replication of pOriT-4Em in E. coli DH5 $\alpha$ or $E$. coli ET12567 (pUZ8002). RepA gene and its flanking sequences on pOriT-4Em, derived from pSM429 (a plasmid from the sea-ice bacterium Pseudoalteromonas sp. BSi20429 [30]), were responsible for the replication and segregational stability of pOriT-4Em in SM9913.

pOriT-4Em was transferred into SM9913 by conjugal transfer using E. coli ET12567 (pUZ8002) as the donor,

Table 1 Sensitivity of SM9913 to different antibiotics

\begin{tabular}{|c|c|c|c|}
\hline & $10 \mu \mathrm{g} / \mathrm{ml}$ & $50 \mu \mathrm{g} / \mathrm{ml}$ & $100 \mu \mathrm{g} / \mathrm{ml}$ \\
\hline Ampicillin & $\ldots$ & $-\ldots$ & -- \\
\hline Kanamycin & $-\cdots$ & -- & --- \\
\hline Chloromycetin & $\ldots$ & ++ & ++ \\
\hline Erythromycin & + & ++ & +++ \\
\hline Tetracycline & $-\cdots$ & -- & $-\cdots$ \\
\hline Streptomycin & -- & -- &.- \\
\hline
\end{tabular}

+: sensitivity. -: insensitivity.

The number of + or - represent the level of sensitivity or insensitivity to antibiotics of different concentrations. 


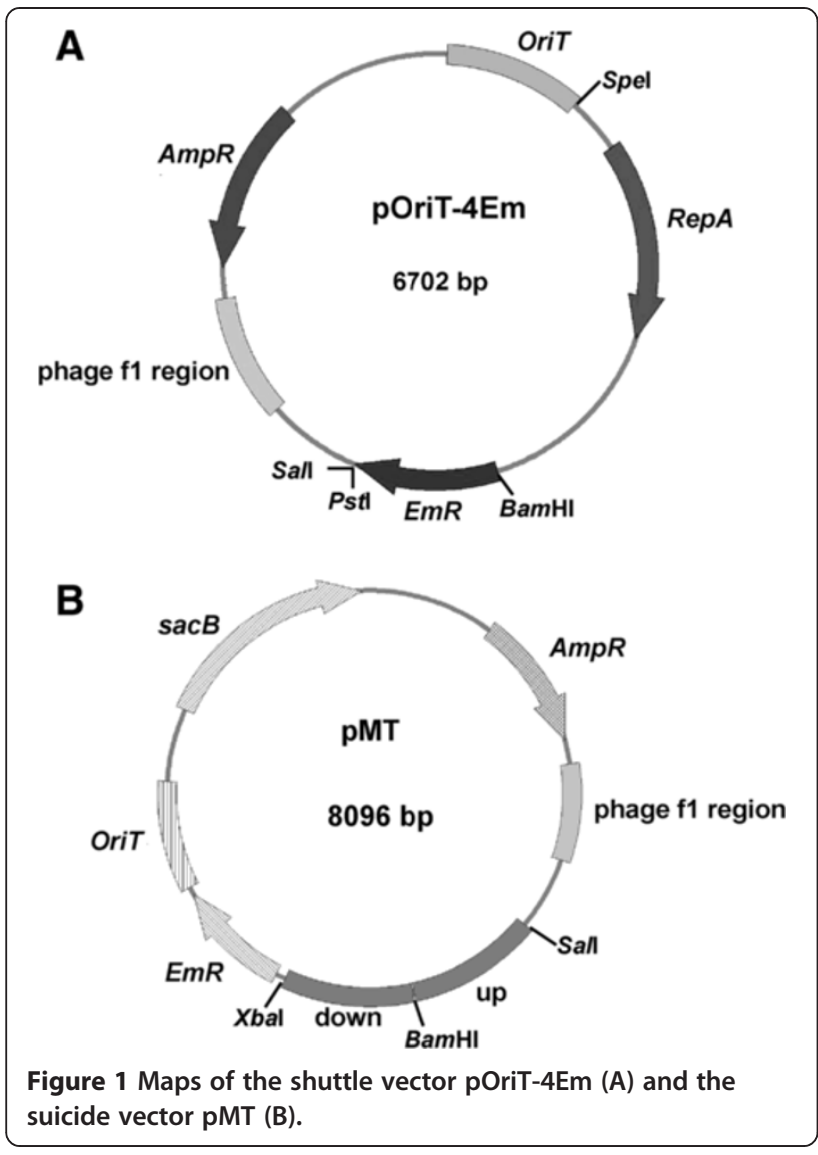

SM9913 as the recipient and erythromycin for screening. Transconjugant colonies were visible on the selective plates at $20^{\circ} \mathrm{C}$ after $36-48 \mathrm{~h}$ incubation. The transfer efficiency was affected by the proportion of donor cells and recipient cells (Figure 2A). The optimal proportion was donor: recipient $=100: 1$. Plasmids were extracted from the transconjugants cultured in marine LB broth at $20^{\circ} \mathrm{C}$ overnight to exclude the false positive clones. The result showed that all tested transconjugants harbored the vector pOriT-4Em (Figure 2B). In this experiment, we found that it seemed that the donor E. coli ET12567 could not survive on the selective plate at $20^{\circ} \mathrm{C}$ after mating with SM9913 for unknown reason. To confirm this, a vector pOriT-4Em- $\triangle R e p A$ that cannot replicate in SM9913 was constructed, and conjugation assay was performed using pOriT-4Em- $\triangle$ RepA as a control. Although E. coli ET12567 harboring pOriT-4Em- $\triangle$ RepA alone could grow on the selective plate at $20^{\circ} \mathrm{C}$ after 7 day incubation, it could not survive after mating with SM9913 (Figure 2A). This result confirmed that the donor E. coli ET12567 cells could not survive after the conjugation, though the reason underlying this phenomenon is not clear yet. Therefore, it can be sure that the colonies shown on the plates 1-6 in Figure 2A should be Pseudoalteromonas sp. SM9913 recombinant colonies. The transfer efficiency was calculated as $1.8 \times 10^{-3}$, which is high enough to perform the gene knockout assay.

\section{Generation of the epsT mutant strain}

As shown in Figure 1B, the suicide vector pMT was constructed using pOriT-4Em as the bone vector by eliminating RepA and its flanking sequences, inserting fragments (up and down) that flanks the epsT gene, and adding counter selective marker $s a c B$ gene. $s a c B$ encodes levansucrase, whose activity will not permit the host to survive in sucrose-containing medium.

The suicide vector pMT was mobilized into SM9913 by intergeneric conjugation. Cells were plated on marine LB solid medium containing erythromycin to screen the clones in which a single crossing over event occurred. In the first homologous recombination, pMT was inserted into the chromosome of SM9913. Since pMT contains two homologous fragments, two different crossing over events may occur depending on which fragment underwent recombination. No matter which crossing over event occurred, each homologous fragment always had two copies in the genome. The epsT gene is flanking by a pair of homologous fragments and the other pair of the homologous fragments was arranged like that in pMT (Figure 3B). So primers UPF/DnR were used to confirm plasmid insertion. Two DNA fragments of different molecular weights were amplified from the positive clones by PCR, as expected (Figure 3A), indicating that a single crossing over event occurred in these clones.

The levansucrase encoded by $s a c B$ gene catalyzes hydrolysis of sucrose and synthesis of levans, which are highmolecular-weight fructose polymers [31]. The expression of $s a c B$ in some gram-negative bacteria is fatal in the presence of sucrose [32], making it a good candidate for counter selection. So the second homologous recombination in SM9913 was performed on the marine LB solid medium containing $30 \%$ sucrose. The mutants were verified by PCR analysis using primers TyzF/TyzR flanking the epsT and by Southern blot hybridization (Figure 4A,B). The results showed that pMT had excised from the target locus in the chromosome of SM9913. Moreover, depending on the site of recombination, back mutants and deletion mutants could be both generated, although back mutants were not selected in this study.

Effect of epsT knockout on the EPS production of SM9913 The epsT gene of SM9913 encodes the UDP-glucose lipid carrier transferase, which may play an important role in the EPS synthesis in SM9913. To determine the effect of epsT knockout on the EPS production of SM9913, wild-type SM9913 and the $\Delta$ epsT mutant were cultured in marine LB broth, and the EPS yields were measured. The EPS produced by wild SM9913 in marine LB broth were $96 \mathrm{mg} / \mathrm{l}$, and those produced by the $\Delta$ eps $T$ mutant 


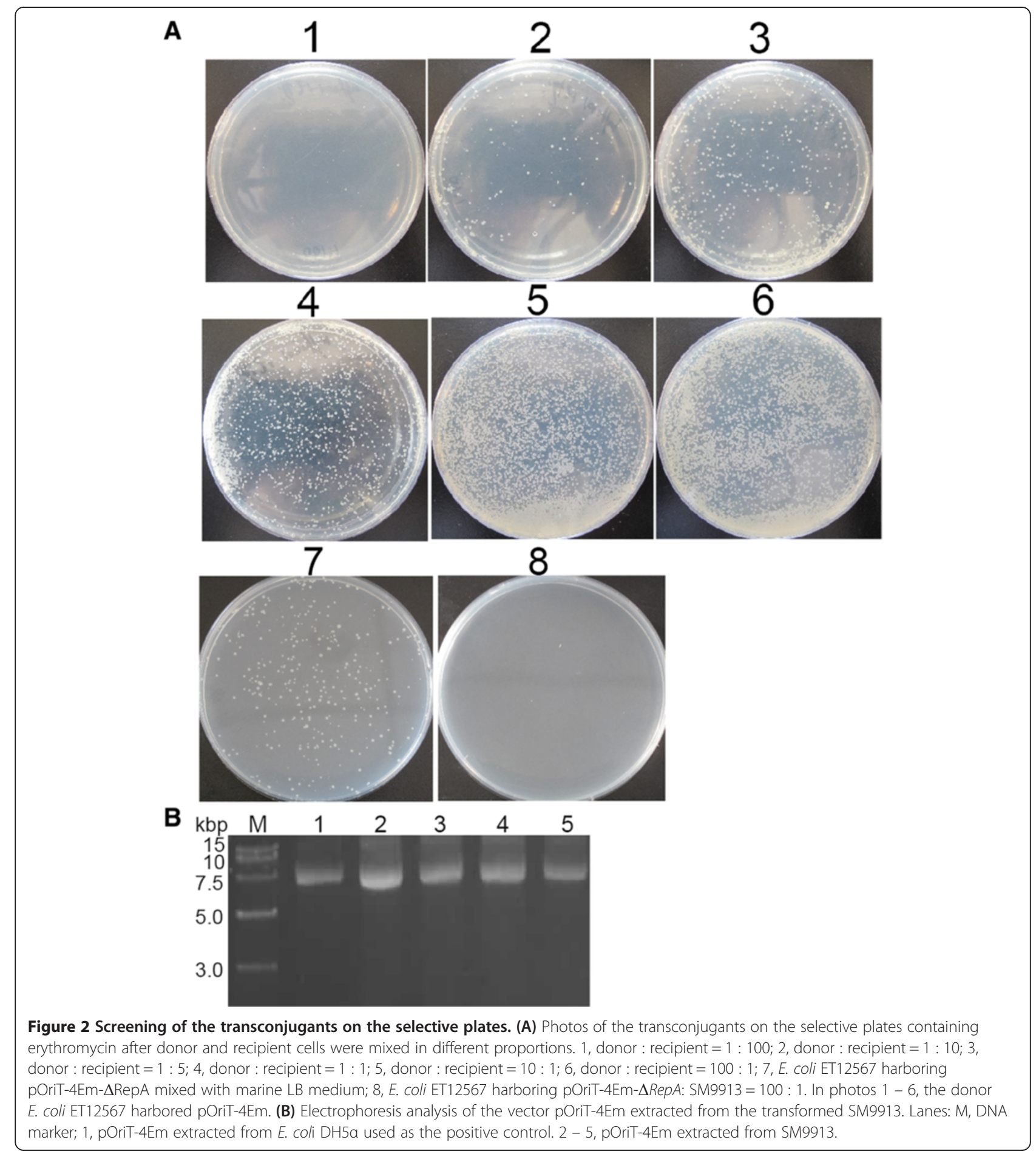

were only $26 \mathrm{mg} / \mathrm{l}$. Therefore, knockout of espT severely affected the EPS production of SM9913, indicating that eps $T$ is an important gene involved in the EPS biosyntheis of SM9913. The residual level of EPS in the $\Delta e p s T$ mutant suggests that there may be either other gene(s) homologous to epsT or other pathway involved in EPS biosynthesis in SM9913.
In genus Pseudoalteromonas, a gene knockout genetic system has been developed in psychrophilic Pseudoalteromonas haloplanktis TAC125 from the Antarctic seawater [16]. In this study, a gene knockout genetic system was successfully developed in the deep-sea psychrophilic strain Pseudoalteromonas sp. SM9913. In the genetic system of Pseudoalteromonas haloplanktis TAC125, $4^{\circ} \mathrm{C}$ was used 


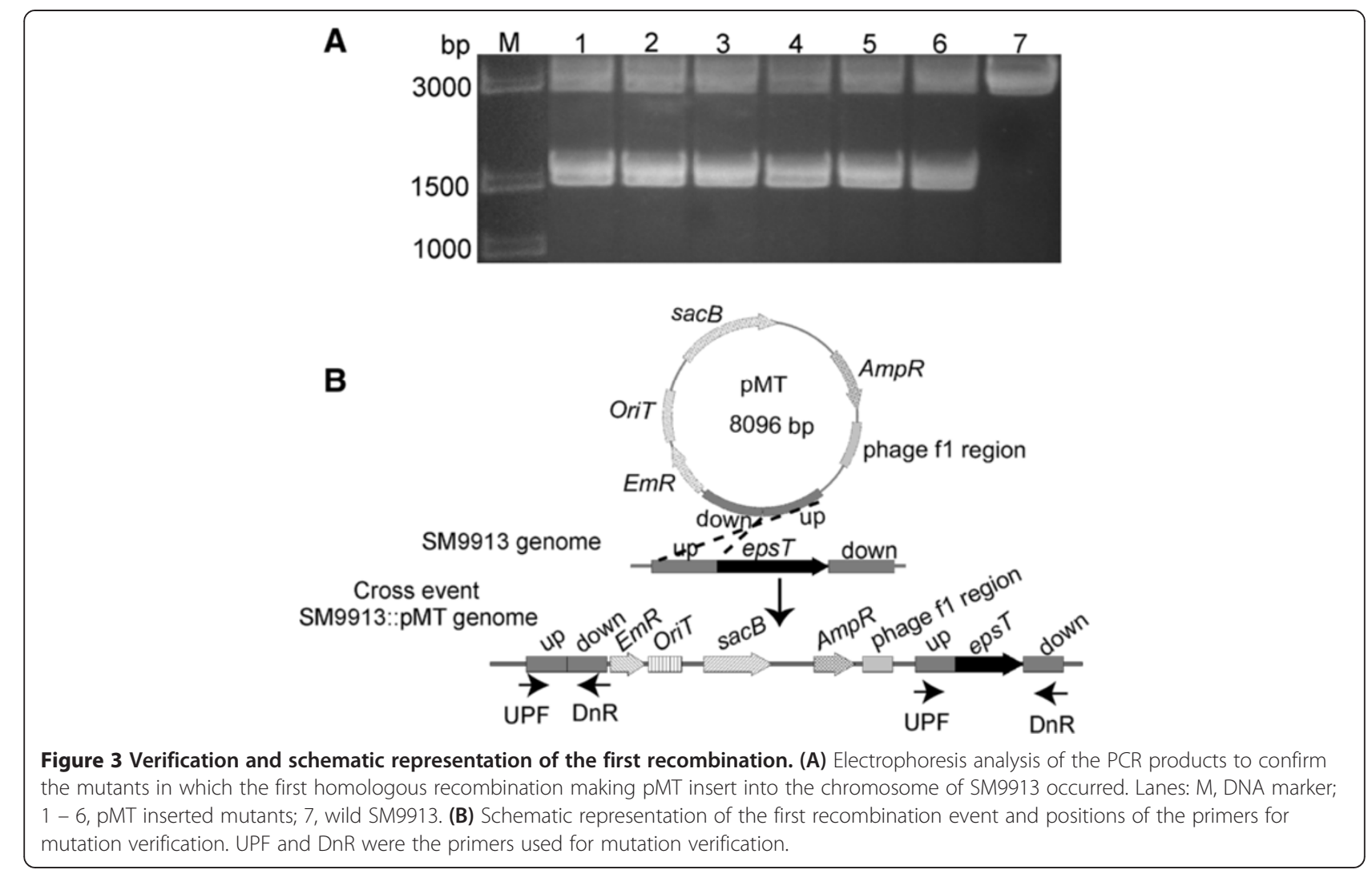

to select the transconjugants to avoid the growth of the donor cells $[16,33]$. In contrast, the transconjugants of SM9913 could be obtained at a wide range of temperatures below $20^{\circ} \mathrm{C}$ without the growth of the donor cells. This can save time because SM9913 grows much faster at its optimal temperature $15-20^{\circ} \mathrm{C}$ than at $4^{\circ} \mathrm{C}$. Moreover, a wide temperature range for transconjugant selection would be helpful for studying the function of genes related to cold-adaptation of psychrophilic bacteria. For some key genes associated with bacterial cold-adaptation, the disruption of them may make bacterial cells difficult to grow at temperature as low as $4^{\circ} \mathrm{C}$, which would disable the selection of transconjugants that have undergone first or double cross-over. In SM9913, this situation can be avoided by selecting the transconjugants at $20^{\circ} \mathrm{C}$.

\section{Conclusions}

Pseudoalteromonas sp. SM9913 is a model strain to study the mechanism of how Pseudoalteromonas adapt to extreme deep-sea environment. In this study, the antibiotic sensitivity of Pseudoalteromonas sp. SM9913 was investigated. Erythromycin was selected for the screening of the transconjugants and the mutants that have underwent the first homologous recombination. A conjugal transfer system was constructed in SM9913 with a wide range of selection temperatures below $20^{\circ} \mathrm{C}$ and a high transfer efficiency of $1.8 \times 10^{-3}$, which is high enough for the genetic manipulation such as heterologous expression and gene knockout in Pseudoalteromonas strains. The epsT gene of SM9913 was successfully deleted with a two-step homologous recombination without introducing

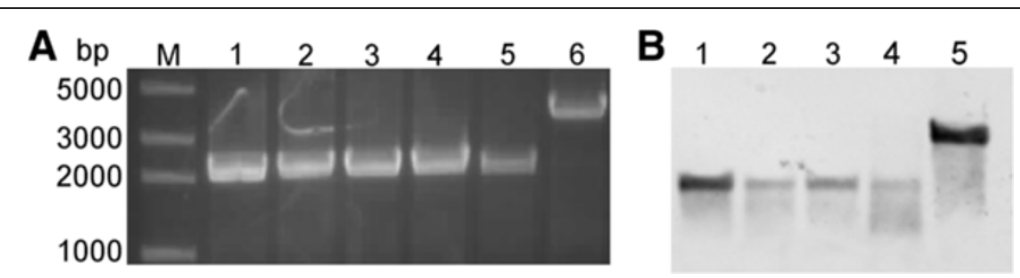

Figure 4 Confirmation of the mutants that underwent the second homologous recombination. (A) Electrophoresis analysis of the PCR products to confirm the cross event. Lanes: M, DNA marker; 1 - 5, epsT deleted mutants; 6, wild type of SM9913. (B) Southern blot hybridization of the mutants and wild SM9913. Lanes: 1 - 4, the deleted mutants; 5, wild type of SM9913. 
any selective marker, making it possible to knock out other genes in the same host. Thus, a method for gene knockout in Pseudoalteromonas sp. SM9913 was successfully constructed, which will facilitate the functional analysis of genes associated with the deep-sea environment adaption of Pseudoalteromonas.

\section{Materials and methods}

\section{Plasmids, bacterial strains and growth conditions}

The plasmids and bacterial strains used in this study were described in Table 2. SM9913 was grown at $15-20^{\circ} \mathrm{C}$ in a marine LB broth (10 g peptone, $5 \mathrm{~g}$ yeast extract, $1 \mathrm{l}$ artificial seawater, $\mathrm{pH} 7.5)$. Escherichia coli $\mathrm{DH} 5 \alpha$ used as the host for gene cloning was grown at $37^{\circ} \mathrm{C}$ in $\mathrm{LB}$ medium [34]. E. coli ET12567 harboring plasmid pUZ8002, a derivative of RK2 plasmid with a mutation in oriT, was used as the donor in intergeneric conjugation experiments, which was cultured at $37^{\circ} \mathrm{C}$ in $\mathrm{LB}$ medium containing chloromycetin $(25 \mu \mathrm{g} / \mathrm{ml})$ and kanamycin $(100 \mu \mathrm{g} / \mathrm{ml})$ because pUZ8002 contains these two resistance genes.

\section{Antibiotics sensitivity assay}

Ampicillin, kanamycin, chloromycetin, erythromycin, tetracycline and streptomycin were used for the antibiotics sensitivity assay of SM9913. SM9913 was grown in marine $\mathrm{LB}$ broth at $20^{\circ} \mathrm{C}$ to late exponential phase, and then $1 \%$ of the culture was inoculated to marine LB broth containing one of the six antibiotics in the final concentration of $10 \mu \mathrm{g} / \mathrm{ml}, 50 \mu \mathrm{g} / \mathrm{ml}$ or $100 \mu \mathrm{g} / \mathrm{ml}$. The culture containing no antibiotic was used as the control. The cultures were incubated at $20^{\circ} \mathrm{C}$ with shaking for $48 \mathrm{~h}$, and then were collected to determine their absorbance of $\mathrm{OD}_{600}$ using a V550 spectrophotometer (Jasco, Japan).

\section{Construction of the shuttle vector pOriT-4Em}

The OriT gene, the conjugative transfer initiation origin, was cloned into pGEM-T Easy vector (Promega, USA) after amplified from pKNG101 using primers OriTF/OriTR (Table 3). Subsequently, a DNA fragment containing the replication protein gene RepA and its flanking sequences that are responsible for stable segregation of the plasmid in SM9913 [30] and erythromycin resistance gene EmR containing its promoter were inserted into the derivative vector at the SpeI and PstI sites. The RepA fragment was amplified from pSM429 with the primers ZF/ZR [30]. The $E m R$ gene containing its promoter was amplified from pMG36e using the primers EmCFB/EmC. Primers ZR and EmCFB were completely reverse complement, and the two DNA fragments were spliced by overlap PCR with introducing a BamHI site between them. The constructed shuttle vector, which can replicate in both $E$. coli and SM9913, was named as pOriT-4Em.

\section{Construction of the suicide vector for epsT gene knockout in SM9913}

Construction of the suicide vector used for gene knockout was based on the shuttle vector pOriT-4Em. An 834 bp upstream homologous fragment was amplified from the upstream of SM9913 epsT gene using primers UPF/UPR and inserted into the SalI and BamHI sites in pOriT-4Em to replace the $E m R$ fragment. A downstream homologous fragment was obtained by PCR from the downstream of SM9913 epsT gene using primers DnF/DnR. EmR gene with its promoter used as the selective marker for the first homologous recombination was amplified from pMG36e with the primers EmF/EmR. Primers DnR and EmF was reverse complement with introducing an $\mathrm{XbaI}$ site between the downstream homologous fragment and the EmR expression cassette. These two DNA fragments were fused by overlap PCR and BamHI and NheI sites were introduced at the $5^{\prime}$ and $3^{\prime}$ ends, respectively. The overlapped PCR product was cloned into pOriT-4EM to replace the RepA and its flanking sequences. Finally, $s a c B$ gene containing its promoter used as the counter selective marker for the second homologous recombination was amplified from pKNG101 using primers sacBF/sacBR and inserted into the vector at the $\mathrm{NcoI}$ and ApaI sites. The constructed suicide vector for epsT gene knockout was named as pMT.

\section{Table 2 Strains and plasmids used in this study}

\begin{tabular}{|c|c|c|}
\hline Strains or plamids & Genotype or markers; characteristics and uses & Source or reference \\
\hline \multicolumn{3}{|l|}{ Strains } \\
\hline Escherichia coli DH5a & supE 44, $\triangle$ lacU169 ( $(980 / a c Z \Delta M 15)$ endA1, recA1, hsdR17, thi-1 I - gyrA96, relA1; gene cloning & Transgen, China \\
\hline Escherichia coli ET12567 & dam, dcm, hsdM, hsdS, hsdR, cat, tet; donor for the conjugal transfer & [35] \\
\hline Pseudoalteromonas sp. SM9913 & Wild type & This work \\
\hline \multicolumn{3}{|l|}{ Plasmids } \\
\hline pUZ8002 & tra, neo, RP4; a derivative of RK2 with a mutation in oriT & [36] \\
\hline pKNG101 & R6K-derived suicide plasmid containing Str and $s a c B$; template for oriT and $s a c B$ amplification & [37] \\
\hline pSM429 & Cryptic plasmid of Pseudoalteromonas sp. Bsi20429; template for RepA & [30] \\
\hline pMG36e & $\mathrm{Em}^{\mathrm{R}}$, pWV01 origin, expression vector for L. lactis; template for EmR amplification & [38] \\
\hline
\end{tabular}


Table 3 Primers used in this article

\begin{tabular}{|c|c|c|c|}
\hline Primer & Sequence $\left(5^{\prime}-3^{\prime}\right)$ & Description & Expected size (bp) \\
\hline OriTF & GCCAGCTCGTCGGTGTAGC & \multirow{2}{*}{ OriT } & \multirow{2}{*}{700} \\
\hline OriTR & CAACAACGTTGCCCGGATCG & & \\
\hline ZF & TGCACTGCAGCAAGACACTGTGAAGGC & \multirow{2}{*}{ RepA and its flanking sequences } & \multirow{2}{*}{2100} \\
\hline ZR & GATTCATTATAACCACGGATCCCTGCCTTTAAGATTTG & & \\
\hline EmCFB & CAAATCTTAAAGGCAGGGATCCGTGGTTATAATGAATC & \multirow{2}{*}{ EmR in pOriT-4Em } & \multirow{2}{*}{825} \\
\hline EmC & GGACTAGTGTTAAGGGATGCAGTITATG & & \\
\hline UPF & ACGCGTCGACGTATGGTGCTGCTGATAACAGC & \multirow{2}{*}{ Upstream homologous fragment of epsT } & \multirow{2}{*}{834} \\
\hline UPR & CGCGGATCCCAGTGTGAGTAGCACCTCAC & & \\
\hline $\mathrm{DnF}$ & CGGGATCCGTGAAAATGCGTACTAA & \multirow{2}{*}{ Downstream homologous fragment of epsT } & \multirow{2}{*}{830} \\
\hline $\mathrm{DnR}$ & CATTATAACCACTCTAGACCACTAAAGTTATCG & & \\
\hline EmF & CGATAACTTTAGTGGTCTAGAGTGGTTATAATG & \multirow{2}{*}{$E m R$ in $\mathrm{pMT}$} & \multirow{2}{*}{825} \\
\hline EmR & CTAGCTAGCGTTAAGGGATGCAGTTTATG & & \\
\hline sacbF & CATGCCATGGCACATATACCTGCCGTTCAC & \multirow{2}{*}{$s a c B$} & \multirow{2}{*}{1900} \\
\hline $\operatorname{sacBR}$ & CCGGGCCCAATGCCAATAGGATATCGGC & & \\
\hline TyzF & GACGATGAATGGAGTGGTAAGATAG & \multirow{2}{*}{ Confirmation of the second recombination } & $3400^{a}$ \\
\hline TyzR & CTCCAATCATGCTGCCATGTTGC & & $2000^{b}$ \\
\hline
\end{tabular}

Construction of conjugal transfer system using pOriT-4Em The shuttle vector pOriT-4Em was transferred from $E$. coli ET12567 (pUZ8002) cells (donor strain) to SM9913 (recipient strain) by interspecific conjugation. The donor cells were grown to logarithmic phase of $\mathrm{OD}_{600} \approx 0.6$ in LB broth containing ampicillin $(100 \mu \mathrm{g} / \mathrm{ml})$, chloromycetin (25 $\mu \mathrm{g} / \mathrm{ml})$ and kanamycin $(100 \mu \mathrm{g} / \mathrm{ml})$ and recipient strains were grown to logarithmic phase of $\mathrm{OD}_{600} \approx 0.6$ in marine LB broth. The cells were washed twice using LB broth for the donor and marine LB broth for the recipient, and then were mixed under different proportions (donor : recipient $=1: 100,1: 10,1: 5,1: 1,10: 1$ and $100: 1$ ). The mixed cells were spread onto a sterile $0.45 \mu \mathrm{m}$-poresize membrane laid on a marine LB plate, which was then incubated at $20^{\circ} \mathrm{C}$ for mating. After $24 \mathrm{~h}$, the cells were resuspended in $1 \mathrm{ml}$ marine $\mathrm{LB}$ medium and spread onto marine LB plates containing $100 \mu \mathrm{g} / \mathrm{ml}$ erythromycin. The plates were incubated at $20^{\circ} \mathrm{C}$ for $36-48 \mathrm{~h}$ until the transconjugant colonies were visible. The transconjugants were inoculated into $5 \mathrm{ml}$ marine LB broth containing $100 \mu \mathrm{g} /$ $\mathrm{ml}$ erythromycin. After the cultures were shaken at $20^{\circ} \mathrm{C}$ overnight, plasmids were extracted using the High-purity Plasmid DNA Mini-preparation Kit (Bioteke, China).

To confirm that E. coli ET12567 could not survive on the selective plate at $20^{\circ} \mathrm{C}$ after mating with SM9913, the $\operatorname{RepA}$ gene in pOriT-4Em was disrupted by digestion with $N h e \mathrm{I}$ and $X b a \mathrm{I}$, and the derivative vector was named pOriT-4Em- $\Delta$ RepA, which could not replicate in SM9913. E. coli ET12567 harboring pOriT-4Em- $\Delta$ RepA was mixed with SM9913 under the proportion of $100: 1$. After mating at $20^{\circ} \mathrm{C}$, the cells were spread onto marine LB plates containing $100 \mu \mathrm{g} / \mathrm{ml}$ erythromycin, which were then incubated at $20^{\circ} \mathrm{C}$ for at least 7 days. In the meantime, a control experiment was performed, in which $E$. coli ET12567 harboring pOriT-4Em- $\Delta$ RepA was mixed with marine LB medium and then spread onto the same selective plate, which was also incubated at $20^{\circ} \mathrm{C}$ for about 7 days until the colonies were visible.

The transfer efficiency was defined as the amount of transconjugants/the amount of donor cells in the mating assay.

\section{Construction of the $\Delta$ eps $T$ mutant strain}

The suicide vector pMT was mobilized into SM9913 by interspecific conjugation. After mating, the cells were spread onto marine LB plates containing $100 \mu \mathrm{g} / \mathrm{ml}$ erythromycin to screen the clones in which a single recombination of pMT inserting into SM9913 genome occurred. The colonies were inoculated into $5 \mathrm{ml}$ marine LB broth and shaken for $24 \mathrm{~h}$, and then the pMT insertion mutants were verified by PCR using primers UPF/DnR after genomic DNA was extracted with the Bacterial DNA Extraction Kit (Bioteke, China). The mutants were then grown at $20^{\circ} \mathrm{C}$ with shaking in liquid marine $\mathrm{LB}$ broth containing no antibiotic, and the culture of late logarithmic phase was inoculated into $5 \mathrm{ml}$ marine LB broth containing no antibiotic and grown at $20^{\circ} \mathrm{C}$ with shaking until $\mathrm{OD}_{600}$ was 0.6 . To select the mutants in which the second recombination occurred, the culture was serially diluted, spread onto marine LB plates containing 30\% sucrose, and 
grown at $20^{\circ} \mathrm{C}$ until colonies appeared. After the colonies were inoculated into $5 \mathrm{ml}$ marine LB broth and shaken for $24 \mathrm{~h}$, the genomic DNA of the mutants was extracted and PCR was performed to verify the recombination event to be back mutation or deletion mutation. The deletion mutation was then tested by southern blot hybridization.

\section{Southern blot hybridization}

Genomic DNA of the mutants was extracted with Bacterial DNA Extraction Kit and treated with the restriction endonuclease HindIII. The digested DNA was separated on $0.8 \%$ agarose gel by electrophoresis, and transferred to positively-charged nylon membrane (GE, UK) by capillary action. The probe containing part of epsT gene and its downstream was amplified from SM9913 genome DNA with primers EpsTF/DnR and labeled with digoxigeninUTP. Detection of target DNA was performed using the DIG High Prime DNA Labeling and Detection kit (Roche, Switzerland) according to the manufacturer's instructions.

\section{Fermentation and yield determination of the EPS of SM9913 and its mutant}

The EPS yields of SM9913 and its $\Delta$ epsT mutant in marine LB broth were determined. SM9913 and the mutant were grown in the medium at $15^{\circ} \mathrm{C}$ for $72 \mathrm{~h}$ with shaking. The cultures were then centrifuged $(10,000 \mathrm{rpm}, 10 \mathrm{~min})$ and the supernatants were dialyzed in deionized water. The concentration of the EPS in the supernatants was determined using the phenol-sulfuric acid method as previously reported with glucose as standard [39].

\section{Competing interests}

The authors declare that they have no competing interests.

\section{Authors' contributions}

$X C$ and $Y Z$ designed the project; $Z Y, D Z, L R$ and $Z M$ performed the research; $Z Y, H S, Q Q, B Z$ and $Y Z$ analyzed the data; $Z Y$ and $X C$ wrote the paper; $X P$, $B X, M S, X S$ and $X Z$ critically reviewed the paper. All authors approved the final manuscript.

\section{Acknowledgements \\ The work was supported by the National Natural Science Foundation of China (grants 31290231, 91228210, 31025001, 31170055, 41176130, 81271896 and 31270064), the Hi-Tech Research and Development Program of China (grants 2011AA090703, 2011AA090704 and 2012AA092103), the China Ocean Mineral Resources R \& D Association (COMRA) Special Foundation (grants DY125-15-T-05), the Special Fund of China for Marine-scientific Research in the Public Interest (grant 201005032-6).}

Received: 9 September 2013 Accepted: 17 January 2014 Published: 22 January 2014

\section{References}

1. Brunnegård J, Grandel S, Ståhl H, Tengberg A, Hall POJ: Nitrogen cycling in deep-sea sediments of the porcupine abyssal plain, NE Atlantic. ProgrOceanogr 2004, 63:159-181.

2. Jørgensen $B B$, Boetius A: Feast and famine-microbial life in the deep-sea bed. Nat Rev Microbiol 2007, 5:770-781.

3. Turley C: Bacteria in the cold deep-sea benthic boundary layer and sedimentwater interface of the NE Atlantic. FEMS Microbiol Ecol 2000, 33:89-99.
4. Schippers A, Neretin LN, Kallmeyer J, Ferdelman TG, Cragg BA, Parkes RJ, Jørgensen BB: Prokaryotic cells of the deep sub-sea floor biosphere identified as living bacteria. Nature 2005, 433:861-864.

5. Nogi Y, Masui N, Kato C: Photobacterium profundum sp.nov., a new, moderately barophilic bacterial species isolated from a deep-seasediment. Extremophiles 1998, 2:1-7.

6. Bidle K, Bartlett $\mathrm{DH}$ : RecD function is required for high-pressure growth of a deep-sea bacterium. J Bacteriol 1999, 181:2330-2337.

7. Lauro FM, Tran K, Vezzi A, Vitulo N, Valle G, Bartlett DH: Large-scale transposon mutagenesis of Photobacterium profundum SS9 reveals new genetic loci important for growth at low temperature and high pressure. J Bacteriol 2008, 190:1699-1709.

8. Bartlett D: Genetic characterization of ompH mutants in the deep-sea bacterium Photobacterium sp. strain SS9. Arch Microbiol 1994, 162:323-328.

9. Allen EE, Bartlett DH: FabF is required for piezoregulation of cis-vaccenicacid levels and piezophilic growth of the deep-sea bacterium Photobacterium profundum strain SS9. J Bacteriol 2000, 182:1264-1271.

10. Allen EE, Facciotti D, Bartlett DH: Monounsaturated but not polyunsaturated fatty acids are required for growth of the deep-sea bacterium Photobacterium profundum SS9 at high pressure and low temperature. Appl Environ Microbiol 1999, 65:1710-1720.

11. Wang $F$, Wang $P, C$ Chen $M$, Xiao X: Isolation of extremophiles with the detection and retrieval of Shewanella strains in deep-sea sediments from the west Pacific. Extremophiles 2004, 8:165-168.

12. Wang F, Wang J, Jian H, Zhang B, Li S, Wang F, Zeng X, Gao L, Bartlett DH, $\mathrm{Yu}$ J, et al: Environmenta adaptation: genomic analysis of the piezotolerant and psychrotolerant deep-sea iron reducing bacterium Shewanella piezotolerans WP3. PLoS One 2008, 3:e1937.

13. Li S, Xiao X, Sun P, Wang F: Screening of genes regulated by cold shock in Shewanella piezotolerans WP3 and time course expression of cold-regulated genes. Arch Microbiol 2008, 189:549-556.

14. Wang F, Xiao X, Ou HY, Gai Y, Wang F: Role and regulation of fatty acid biosynthesis in the response of Shewanella piezotolerans WP3 to different temperatures and pressures. J Bacterio/ 2009, 191:2574-2584.

15. Chen Y, Wang F, Xu J, Mehmood MA, Xiao X: Physiological and evolutionary studies of NAP systems in Shewanella piezotolerans WP3. ISME J 2011, 5:843-855.

16. Giuliani M, Parrilli E, Pezzella C, Rippa V, Duilio A, Marino G, ML T: A novel strategy for the construction of genomic mutants of the Antarctic bacterium Pseudoalteromonas haloplanktis TAC125. Methods Mol Bio 2012, 824:219-233.

17. Zeng $X$, Xiao X, Wang P, Wang F: Screening and characterization of psychrotrophic, lipolytic bacteria from deep-sea sediments. J Microbiol Biotechnol 2004, 14:952-958.

18. Zhou MY, Chen XL, Zhao HL, Dang HY, Luan XW, Zhang XY, He HL, Zhou BC, Zhang $Y Z$ : Diversity of both the cultivable protease-producing bacteria and their extracellular proteases in the sediments of the South China Sea. Microb Ecol 2009, 58:582-590.

19. Patantis G, Chasanah E, Zilda DS, Waluyo IB: Bacterial diversity of the deep sea of Sangihe Taluad, Sulawesi. Squalen 2012, 7:19-27.

20. Chen XL, Zhang YZ, Gao PJ, Luan XW: Two different proteases produced by a deep-sea psychrotrophic bacterial strain, Pseudoaltermonas sp. SM9913. Mar Biol 2003, 143:989-993.

21. Qin GK, Zhu LZ, Chen XL, Wang PG, Zhang YZ: Structural characterization and ecological roles of a novel exopolysaccharide from the deep-sea psychrotolerant bacterium Pseudoalteromonas sp. SM9913. Microbiology 2007, 153:1566-1572.

22. Cui Z, Lai Q, Dong C, Shao Z: Biodiversity of polycyclic aromatic hydrocarbon-degrading bacteria from deep sea sediments of the Middle Atlantic Ridge. Environ Microbiol 2008, 10:2138-2149.

23. Holmstrom C, Kjelleberg S: Marine Pseudoalteromonas species are associated with higher organisms and produce biologically active extracellular agents. FEMS Microbiol Ecol 1999, 30:285-293.

24. Kurusu Y, Yoshimura S, Tanaka M, Nakamura T, Maruyama A, Higashihara T: Genetic transformation system for a psychrotrophic deep-sea bacterium: isolation and characterization of a psychrotrophic plasmid. Mar Biotechnol 2001, 3:96-99.

25. Chen $X L$, Sun $C Y$, Zhang $Y Z$, Gao PJ: Effects of different buffers on the thermostability and autolysis of a cold-adapted protease MCP-01. J Protein Chem 2002, 21:523-527. 
26. Zhao GY, Chen XL, Zhao HL, Xie BB, Zhou BC, Zhang YZ: Hydrolysis of insoluble collagen by deseasin MCP-01 from deep-sea Pseudoalteromonas sp. SM9913: collagenolytic characters, collagen-binding ability of C-terminal polycystic kidney disease domain, and implication for its novel role in deep-sea sedimentary particulate organic nitrogen degradation. J Biol Chem 2008, 26:36100-36107.

27. Yan BQ, Chen XL, Hou XY, He H, Zhou BC, Zhang YZ: Molecular analysis of the gene encoding a cold-adapted halophilic subtilase from deep-sea psychrotolerant bacterium Pseudoalteromonas sp. SM9913: cloning, expression, characterization and function analysis of the C-terminal PPC domains. Extremophiles 2009, 13:725-733.

28. Qin QL, Li Y, Zhang YJ, Zhou ZM, Zhang WX, Chen XL, Zhang XY, Zhou BC, Wang $L$, Zhang YZ: Comparative genomics reveals a deep-sea sedimentadapted life style of Pseudoalteromonas sp. SM991. ISME J 2011, 5:274-284

29. Nishino K, Yamaguchi A: Analysis of a complete library of putative drug transporter genes in Escherichia coli. J Bacteriol 2001, 183:5803-5812.

30. Zhao DL, Yu ZC, Li PY, Wu ZY, Chen XL, Shi M, Yu Y, Chen B, Zhou BC, Zhang YZ: Characterization of a cryptic plasmid pSM429 and its application for heterologous expression in psychrophilic Pseudoalteromonas. Microb Cell Fact 2011, 10:30.

31. Dedonder R: Levansucrase from Bacillus subtilis. Methods Enzymol 1966, 8:500-505.

32. Pelicic V, Reyrat JM, Gicquel B: Expression of the Bacillus subtilis sacB gene confers sucrose sensitivity on mycobacteria. J Bacteriol 1996, 178:1197-1199.

33. Duilio A, Tutino ML, Marino G: Recombinant protein production in Antarctic Gram-negative bacteria. Methods Mol Biol 2004, 267:225-237.

34. Sambrook J, Fritsch EF, Maniatis T: Molecular cloning: a laboratory manual. 2nd edition. New York: Cold Spring Harbor Laboratory Press; 1989

35. MacNeil DJ, Gewain KM, Ruby CL, Dezeny G, Gibbons PHTM: Analysis of Streptomyces avermitilis genes required for avermectin biosynthesis utilizing a novel integration vector. Gene 1992, 111:61-68.

36. Paget MS, Chamberlin L, Atrih A, Foster SJ, Buttner MJ: Evidence that the extracytoplasmic function sigma factor sigmaE is required for normal cell wall structure in Streptomyces coelicolor A3(2). J Bacteriol 1999, 181:204-211.

37. Kaniga K, Delor I, Cornelis GR: A wide-host-range suicide vector for improving reverse genetics in gram-negative bacteria: inactivation of the blaA gene of Yersinia enterocolitica. Gene 1991, 109:137-141.

38. van de Guchte M, van der Vossen JM, Venema G: Construction of a lactococcal expression vector: expression of hen egg white lysozyme in Lactococcus lactis subsp. lactis. Appl Environ Microbiol 1989, 55:224-228.

39. Dubois M, Gilles KA, Hamilton JK, Rebers PTFS: Colorimetric method for determination of sugars and related substances. Anal Chem 1956, 28:350-356

doi:10.1186/1475-2859-13-13

Cite this article as: Yu et al:: Development of a genetic system for the deep-sea psychrophilic bacterium Pseudoalteromonas sp. SM9913. Microbial Cell Factories 2014 13:13.

\section{Submit your next manuscript to BioMed Central and take full advantage of:}

- Convenient online submission

- Thorough peer review

- No space constraints or color figure charges

- Immediate publication on acceptance

- Inclusion in PubMed, CAS, Scopus and Google Scholar

- Research which is freely available for redistribution 